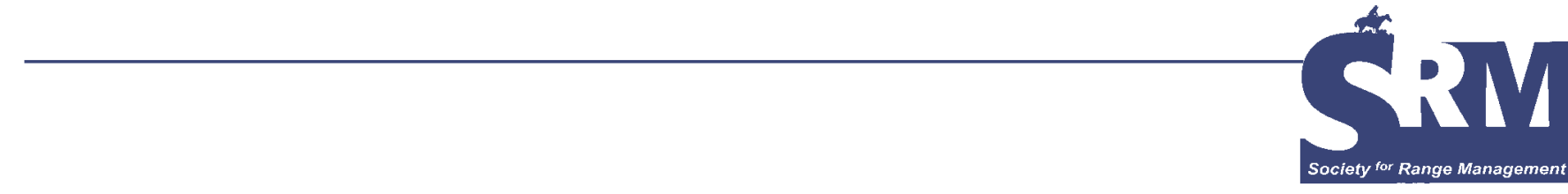

\title{
Climate Change Impacts on African Rangelands
}

\section{By Timm Hoffman and Coleen Vogel}

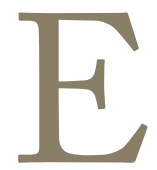

ven though Africa has contributed the least to global greenhouse gas emissions, it is considered the continent most susceptible to climate change impacts because of 1) the large proportion of people who live in the subtropics, a region predicted to be affected by increased temperature and reduced precipitation; 2) the high dependence of people on natural resources, livestock, and agriculture for their livelihoods; 3) extreme poverty in many parts of Africa, which makes it difficult for affected people to respond to an increased incidence of drought and floods; and 4) the degraded state of Africa's natural resources, which renders them less resilient to the impact of higher temperatures and lower and more variable precipitation.

\section{Africa's Rangelands and Their Importance to the Continent}

Africa covers about 30 million $\mathrm{km}^{2}$ (11.6 million square miles) and, although it is slightly smaller in size than Asia, it is unique in having its land mass distributed more or less equally in both hemispheres. Its vast length $(8,050 \mathrm{~km}$ or 4,990 miles), breadth $(7,560 \mathrm{~km}$ or 4,867 miles) and elevation range (-153 to $5,895 \mathrm{~m}$ or -500 to 19,340 feet) results in tremendous variability across the continent driven by several large, complex atmospheric features (e.g., the West African Monsoon, the Intertropical Convergence Zone, and the El Niño-Southern Oscillation). These weather systems influence the size and functioning of the major land cover classes on the continent from daily to millennium time scales (Fig. 1) and interact with each other in complex ways that are not well understood at present.

Africa's rangelands are comprised mostly of the woodlands/shrublands and grasslands land cover classes (43\% of
Africa; nearly 13 million $\mathrm{km}^{2}$ or 5.1 million square miles), although a significant amount of livestock production also occurs within the agricultural lands and some also on the margins of bare soil environments, particularly during above-average rainfall years. Their composition and productivity are influenced primarily by rainfall, fire, and grazing, although over longer time frames, changes in temperature and the concentration of atmospheric $\mathrm{CO}_{2}$ are also important.

A wide range of land use systems, governed by often complex land tenure arrangements, affect Africa's rangelands. Within this complexity, there are three main types of livestock systems: 1) industrial livestock systems, 2) agropastoral and pastoral systems, and 3) smallholder croplivestock systems. Irrespective of the system used, however, livestock are central to the livelihoods of more than 200 million Africans who rely on them for income from sales of milk, meat, and skins, and for protein consumption, draft power, and ritual and spiritual needs, among other uses. Owning livestock is one way by which many people are able to diversify their risk, increase their assets, and improve their resilience to sudden changes in climate, disease outbreaks, and unfavorable market fluctuations.

Agricultural production (of which livestock production is an important part) not only contributes to the livelihoods of individual households, but also to the continent's economy as a whole. It accounts for $20-30 \%$ of the gross domestic product of sub-Saharan Africa and 55\% of African exports. Despite rapid rates of urbanization, more than $60 \%$ of Africans still live in rural areas, and more than $56 \%$ of the total labor force (estimated at over 200 million people) was engaged in some form of agricultural activity in 2002. Estimates are that nearly $90 \%$ of the poorest inhabitants work primarily in agriculture and more than two thirds own 


\section{The Land Cover of Africa for the year 2000}

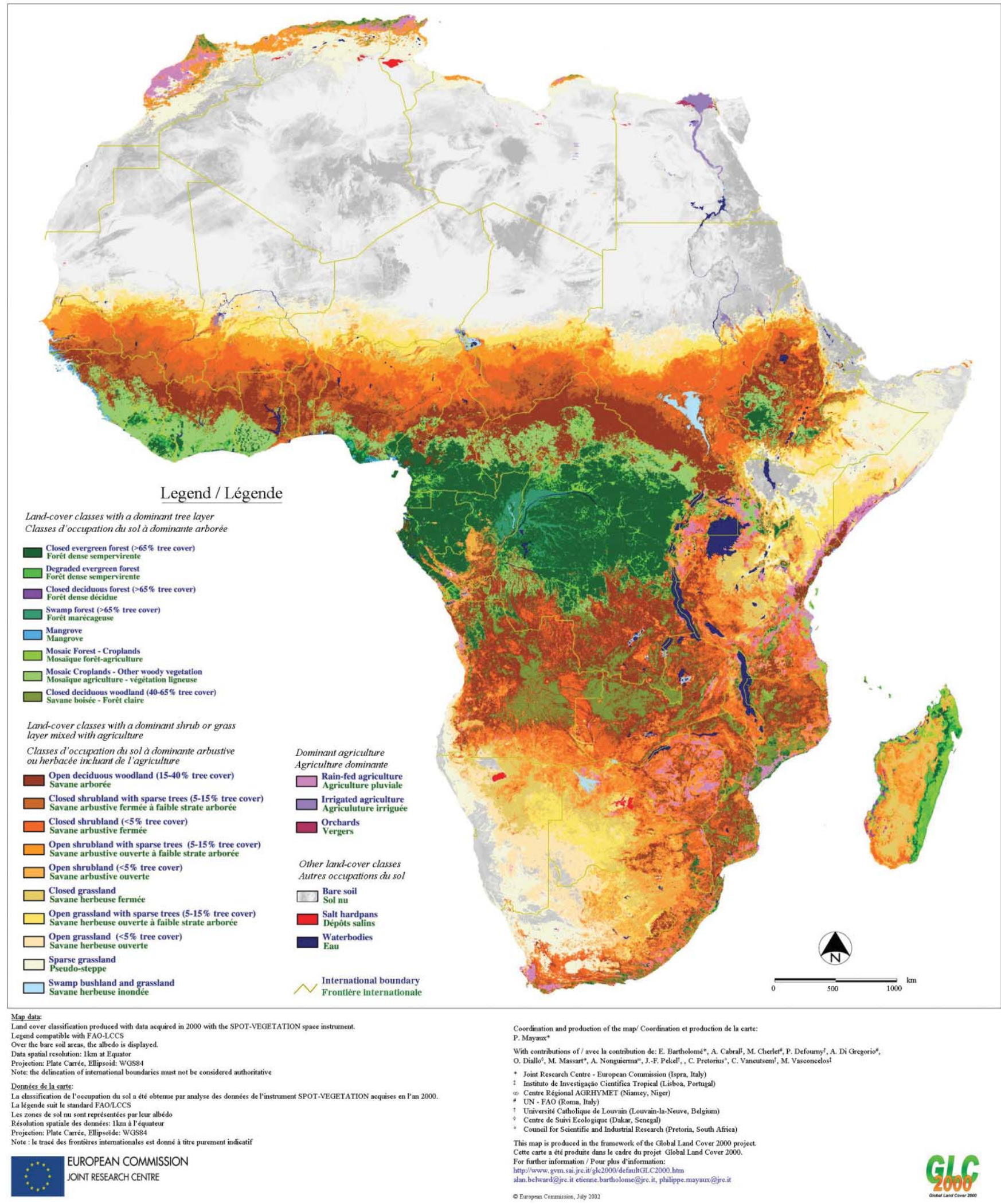

Figure 1. Land cover in Africa (from Mayeux et al. 2000). 
livestock, although de-agrarianization and diversification into other activities have been noted.

Despite the natural and mineral riches of Africa, nearly $60 \%$ of the continent's 812 million people live on less than US $\$ 1$ a day, and the proportion of people living below the poverty line increased in the last $15 \mathrm{yr}$ of the 20th century. Even though Africa spends up to US $\$ 20$ billion each year on food imports (in addition to the US $\$ 2$ billion it receives annually in food aid), about $26 \%$ of the population is undernourished. Given recent global climate change projections, it is appropriate to investigate the likely impact of such changes on the continent's rangeland resources and on the people who use them.

\section{Climate Change Over Africa's Rangelands Historical Trends}

Similar to global trends, Africa warmed by about $0.5^{\circ} \mathrm{C}$ $\left(0.9^{\circ} \mathrm{F}\right)$ in the 20th century with the most rapid warming occurring between 1910-1930 and after 1970, particularly in southern and northern Africa. Rainfall trends and patterns are more difficult to determine and significant regional differences are evident. For example, the alternating wet and dry periods in the Sahel, particularly the dry period after 1970, have been studied in detail. There is some evidence that rainfall increased in parts of eastern Africa during the 20th century. Other areas of the continent, such as Southern Africa, have experienced marked interdecadal variability, which adds to the difficulty of managing complex risks in several African environments. A closer alignment of historical climate data with comprehensive land use histories is urgently needed to understand the full extent of changes that have occurred in African rangelands over the course of the 20th century (see sidebar).

\section{Future Climate Projections}

What are the future climate change projections as they affect Africa's rangelands in the 21st century?

- Temperature will increase by between $2-6^{\circ} \mathrm{C}\left(3.6-10.8^{\circ} \mathrm{F}\right)$ by the end of the 21 st century, depending on the region and greenhouse gas emission scenario used. Increases will very likely be greater throughout Africa and in all seasons than the global average, with the drier northern and southern Africa subtropical regions warming more than the moister tropical regions of western, central, and eastern Africa, as well as the coastal environments.

- Annual rainfall is likely to decrease in southern and northern Africa with the Mediterranean areas of both regions being particularly badly affected. It is likely, however, that rainfall could increase in eastern Africa. Model projections for the Sahel, the Guinean Coast, and the southern Sahara have returned mixed results and are considered unclear at present.

- Changes in variability (e.g., periods of extended dry spells, wet spells, pattern of rainfall including numbers of rain days, etc.) is an additional area of concern. Although limited by the number of studies and data to support very
Africa's Environmental History and the Impacts of Climate Change

Detailed inspection of the historical climate records suggests that African temperatures have increased by $0.5^{\circ} \mathrm{C}$ over the course of the 20th century and that rainfall has decreased in some parts but not in others. Most future projections paint a gloomy picture for African rangelands. But how have they changed over the course of the 20th century in response to the key drivers of climate and land use and what does this tell us about likely future changes?

Although Africa's drylands are considered some of the most degraded in the world, several historical studies contest the litany of environmental destruction in Africa. These include the following:

- West Africa: an analysis of the pattern and direction of vegetation change within the forest-savanna mosaic around Kissidougou (Guinea) showed that in some cases forests are not relics of destruction but have been created by people around their settlements.

- East Africa: A 30-yr study in northern Ethiopia by Jan Nyssen and his colleagues showed how erosion has decreased and how hydrological function, vegetation cover, and agricultural production all have improved as a result of better management of natural resources in the region.

- Southern Africa: A series of repeat photographs that document environmental change in semiarid Namaqualand has shown an increase in vegetation cover at many sites, including riverine areas following a reduction in livestock and an abandonment of marginal agricultural lands.

These studies all describe an "improvement" in rangeland condition and plant cover despite increases in temperature and human populations over the course of the 20th century. They emphasize that climate change projections alone are not enough to build an understanding of what Africa's rangelands will look like in the future. The litany of future environmental collapse needs to be balanced with well-documented environmental histories that track change over time and provide benchmarks for understanding the rate and extent of future change.

conclusive statements on trends at present, emerging research shows that droughts are likely to increase in total area affected and that heavy precipitation events are likely to increase generally beyond that expected from changes in the mean. More than 250 million Africans live in drought-prone areas. Changes in the frequency and magnitude of drought could add to the complex riskmanagement portfolios that many people use to sustain their livelihoods, and such changes will make recovery more difficult because periods between significant events will be shortened.

- There is considerable uncertainty associated with these projections. This uncertainty has arisen in part because a 
growing, but nonetheless limited, understanding of the key drivers of African climates is frustrated by poor data and monitoring sources and further complicated by trying to understand the web of interaction between climate, land cover/atmospheric feedback processes, and dust and biomass aerosols. For example, depending on the scenario and model used, rainfall changes in the West African Sahel range from +15 to $-50 \%$. There is also great uncertainty as to whether the Sahara is going to get wetter or drier or what the impact of climate change is likely to be on the Nile River system and on African agriculture in general. A comparison of the maps of projected climate change impacts on the vegetation of Africa produced by Thornton et al. and Fischlin et al. (see Additional Reading) is a sobering reminder of the high degree of uncertainty in environmental responses to global warming.

\section{Implications of Climate Change for Africa's Rangeland Resources and Ecosystem Services}

\section{Change in Water Resources}

The impact of climate change on Africa's hydrological resources varies within each of the three main hydrological regions (dry, intermediate, or wet, based on their perennial drainage densities determined by total perennial stream length per unit area). The impact of climate change will be greatest in the intermediate region, which receives between $400-1,000 \mathrm{~mm}$ of rain per year. The impact will also be felt nonlinearly and drier areas within this range will experience significantly greater losses in surface drainage with a decrease in rainfall than wetter areas. For example, a 10\% drop in rainfall (which is well within the bounds projected for southern Africa) in a region of $1,000 \mathrm{~mm}$ per year will result in a decline in surface drainage of only $17 \%$, whereas in areas of $500 \mathrm{~mm}$ per year the same decrease in rainfall will result in a $50 \%$ decline in surface drainage. Such a dramatic response in surface drainage to decreasing rainfall could have devastating consequences for this intermediate hydrological zone, which covers $25 \%$ of the continent, affects $75 \%$ of the 48 mainland countries in Africa, and includes most of the densely populated savanna rangelands of southern and eastern Africa and a significant part of the Sahel. The decrease in surface drainage, coupled with an increase in water demand by livestock and people, as a result of increased temperatures will challenge traditional coping strategies and likely increase tensions around already scarce water resources.

\section{Change in Rangeland Productivity, Forage \\ Production, and Species Composition}

Rainfall and temperature are key determinants of rangeland productivity. The effect of future climate change projections on the length of the growing period (LGP), which integrates the influence of temperature and rainfall on productivity, results in a number of potential impacts, including changes in the length of the growing season for certain agricultural activities. The combined impact of changes in temperature and rainfall will result in a decrease of LGP in much of sub-Saharan Africa and in some cases this decrease will be severe (Fig. 2). Areas where decreases in LGP $>20 \%$ are predicted consistently include large parts of southern Africa, particularly where cropping is marginal, as well as a broad swathe in the Sahel, in the ecotone between the savanna and desert biomes of the northern African subtropics. A significant reduction in LGP by 2050 was also predicted in most models for the more arid parts of eastern Africa. However, there are competing analyses that suggest a more benign future for much of Africa's rangelands.

Temperature, rainfall, and atmospheric $\mathrm{CO}_{2}$ concentration interact with grazing and land cover change to influence rangeland quality and composition. Increased temperature, for example, not only increases drought stress in plants but also increases lignification of their tissues, which affects both its digestibility as well as its rate of decomposition. Increased temperature and lower rainfall also increases vegetation flammability, resulting in a shift in species composition as a result of an increased fire frequency. The amount and timing of rainfall on its own also has an important influence on rangeland species composition in both the short- and long-term, primarily through its differential effect on the growth and reproduction of key forage species. An extended drought can result in the mortality of

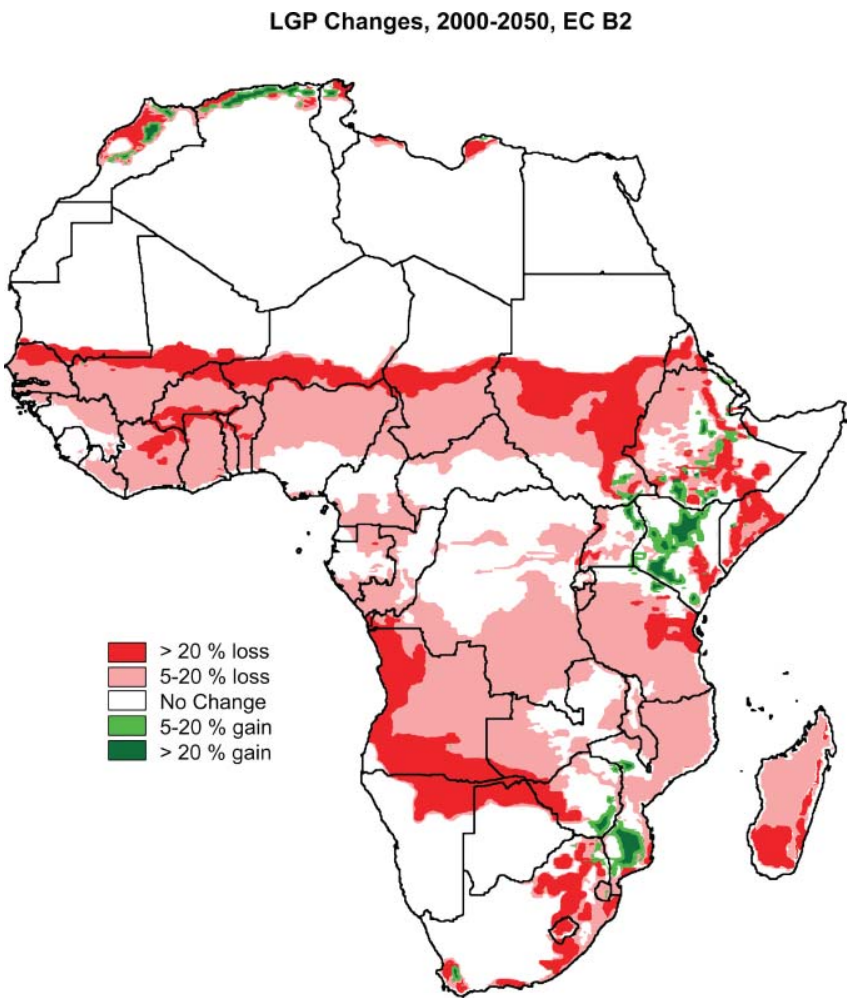

Figure 2. Percentage changes in length of growing period to 2050, ECHam4 and Scenario B2 (Thornton et al. 2006b, fig. 7[B]). Figure redrawn by Shawn Salley. 
perennial plants and the switch to an annual-dominated flora.

\section{Change in Land Use Systems and} Rangeland-Based Livelihoods

The general reduction in productivity projected for Africa's rangelands will have important negative consequences for development potential and likely will result in a shift in agricultural activities. Some projections suggest that in marginal crop production areas the decrease in the length of the growth period (LGP) and an increase in rainfall variability will render cultivation too risky and will result in a switch to more rangeland-based livestock production systems. There is also likely to be a switch to breeds and species (e.g., from cattle to sheep, goats, and camels) that are better adapted to more marginal conditions. Other changes include a greater frequency of loss of livestock assets, particularly through drought and through an expansion of vector-borne (e.g., ticks) diseases into cooler areas, a reduction in income, increased income inequalities, and a general reduction in livelihood security for people who derive their livelihoods primarily, or even in part, from Africa's rangelands.

However, reducing all changes occurring on rangelands to "climate change" is a gross over-simplification and can be misleading. Recent assessments in parts of Africa, for two contrasting areas (the African Sahel and eastern Karoo, South Africa), showed that land cover changes in both cases were not only determined by rainfall changes but also by complex rangeland management decisions. Climate (e.g., temperature and rainfall) is important, but the combined impact of grazing and stocking strategies, and other factors influencing decision making, are also key in shaping rangelands. Rather than singular stresses shaping and dominating the environment, a range of other factors also need to be understood, including the interaction of human settlements and changes in land use, as well as how various policies have an impact on land use change. Much more work also is required on how policy and understandings of rangeland changes are framed, reproduced, and mainstreamed into practice (see sidebar). These various interactions can act as critical drivers of rangeland bringing with them potential changes, including conflicts between different land-use sectors.

\section{Management and Policy Implications}

Given that Africa will be particularly negatively affected by climate change, what steps can be taken to mitigate and adapt to its impacts? Firstly, we need to know more about how African rangelands have responded to changing climates in the past and how land use practices have combined with climate change to influence the production and composition of these systems (see sidebar). Climate change projections largely ignore the complex interplay that exists between people, their environment, and the linked urbanrural societies in which they live. The extent and rate of past environmental change and an understanding of the reasons for such changes is required.

Secondly, and somewhat related, we also need to develop better monitoring systems, both of climate and of ecosystem response, and we need to expand our capacity as Africans, through collaboration with international initiatives and agencies, to conceive, fund, implement, and manage such monitoring programs. Several major climate change adaptation-relevant initiatives and activities are already underway in Africa. A number of donor-driven activities as well as various institutions have also been established to address the role of such activities in shaping rangelands (e.g., the origins, outcomes, and processes of engagement of such activities).

Thirdly, we need to intervene to lessen the impact of climate change on Africa's most vulnerable communities by adopting responses that include direct intervention to facilitate micro-level adaptations and technological developments, as well as market responses and institutional and policy changes. Although this broad general approach is an excellent starting point for any intervention strategy, knowing what approach could be used most effectively in which area is an important first step in knowing how to deal with the impact of climate change and a greater understanding of the complex interactions in various areas is also required.

Finally, Africa's rangelands are dominated by extensive livestock production systems and securing these assets, particularly for poorer households in the face of climate change, is a major challenge. Some of the most important suggestions for how to do this focus on enabling herd mobility through securing better access to water resources and increasing access to more land, particularly when it is marginal for crop production. Other suggestions include the improvement of early warning systems and dissemination of this information, enabling pastoral groups to better engage with policy debates, building stronger conflict management institutions, and supporting a diversification of livelihoods, perhaps through tourism and conservation. The nonequilibrium perspective that depicts ecosystems as existing in multiple stable states depending on both external and internal drivers is a useful paradigm to follow in this regard.

It should be remembered, however, that the impact of climate change is not the only factor that will affect livestock production on the continent and the rangelands that sustain these activities. Although these impacts should not be ignored, they should also not be exaggerated. High population growth (estimated at 1.9\% between 1992 and 2002), rapid rates of urbanization (up to $3.5 \%$ per annum in some countries), land reform initiatives, and the high mortality of agricultural workers from HIV/AIDS (which could be as high as $26 \%$ in badly affected countries in the next two decades) are only a few of many other factors that will influence Africa's agricultural environments, including her rangelands, in the 21st century. Climate change impacts might not all be negative, and a better understanding of where and why responses have been successful is also required. 


\section{Acknowledgments}

T. Hoffman would like to acknowledge the support of the BIOTA project, sponsored by the German Federal Ministry of Education and Research (promotion numbers 01LC0024 and 01LC00024A).

\section{Additional Reading}

Boko, M., I. Niang, A. Nyong, C. Vogel, A. Githeko, M. Medany, B. Osman-Elasha, R. Tabo, and P. Yanda. 2007. Africa. In: M. L. Parry, O. F. Canziani, J. P. Palutikof, P. J. van der Linden, and C. E. Hanson [EDS.]. Climate change 2007: impacts, adaptation and vulnerability. Contribution of Working Group II to the Fourth Assessment Report of the Intergovernmental Panel on Climate Change. Cambridge, United Kingdom: Cambridge University Press. p. 433-467.

Christensen, J. H., B. Hewitson, A. Busuioc, A. Chen, X. GaO, I. Held, R. Jones, R. K. Kolli, W.-T. Kwon, R. Laprise, V. Magaña Rueda, L. Mearns, C. G. Menéndez, J. Räisänen, A. Rinke, A. SARR, And P. Whetton. 2007. Regional climate projections. In: S. Solomon, D. Qin, M. Manning, Z. Chen, M. Marquis, K. B. Averyt, M. Tignor, and H. L. Miller [EDS.]. Climate change 2007: the physical science base. Contribution of Working Group 1 to the Fourth Assessment Report of the Intergovernmental Panel on Climate Change. Cambridge, United Kingdom: Cambridge University Press. p. 847-940.

Elasha, B. O., M. Medany, I. Niang-Diop, T. Nyong, R. TABO, AND C. VoGEL. 2006. Background paper on impacts, vulnerability and adaptation to climate change in Africa for the African workshop on adaptation-implementation of decision 1/CP.10 of the United Nations Framework Convention on Climate Change; 21-23 September 2006. Accra, Ghana: UNFCC. 54 p.

Fischlin, A., G. F. Midgley, J. T. Price, R. Leemans, B. Gopal, C. Turley, M. D. A. Rounsevell, O. P. Dube, J. Tarazona, AND A. A. VelichKo. 2007. Ecosystems, their properties, goods, and services. In: M. L. Parry, O. F. Canziani, J. P. Palutikof, P. J. van der Linden, and C. E. Hanson [EDs.]. Climate change 2007: impacts, adaptation and vulnerability. Contribution of Working Group II to the Fourth Assessment Report of the Intergovernmental Panel on Climate Change. Cambridge, United Kingdom: Cambridge University Press. p. 211-273.

Hulme, M., J. Arntzen, T. Downing, R. Leemans, J. Malcolm, N. Reynard, S. Ringrose, and D. Rogers. 1996. Climate change and southern Africa: an exploration of some potential impacts and implications in the SADC region. Norwich, United Kingdom: Climatic Research Unit, University of East Anglia. 104 p.

Thornton, P., M. Herrero, A. Freeman, O. Mwai, E. Rege, P. Jones, AND J. McDermotT. 2006a. Vulnerability, climate change and livestock-research opportunities and challenges for poverty alleviation. Nairobi, Kenya: International Livestock Research Institute. 23 p.

Thornton, P. K., P. G. Jones, T. Owiyo, R. L. Kruska, M. Herrero, P. Kristjanson, A. Notenbaert, N. Bekele, And A. OMolo, With Contributions from V. ORindi, B. Otiende, A. Ochieng, S. Bhadwal, K. Anantram, S. Nair, V. KumAR, AND U. KULKAR. 2006b. Mapping climate vulnerability and poverty in Africa. Report to the Department for International Development. Nairobi, Kenya: International Livestock Research Institute. $171 \mathrm{p}$.

United Nations Environment Programme. 2006. African environment outlook 2: our environment, our wealth. Nairobi, Kenya: UNEP. 542 p.

Authors are Professor, Plant Conservation Unit, Botany Department, University of Cape Town, Cape Town, South Africa,Timm.Hoffman@uct.ac.za (Hoffman); and Professor, School of Geography, Archeology and Environmental Studies, University of the Witwatersrand, Johannesburg, South Africa (Vogel). 